\title{
The Insulin Releasing Activities of Extracts of Pork Intestine
}

\author{
A.J. Moody, J. Markussen, A. Schatch Fries, C. Steenstrup and F. Suddby \\ Novo Research Institute, Fuglebakkevej 115, Copenhagen, Denmark
}

W. Malatsse and F. Malatsse-Lagae

Laboratories of Experimental Medicine and Anatomo-Pathology, Free University of Brussels, Brussels, Belgium

Received: June 6, 1969

\begin{abstract}
Summary. Acid-ethanol extracts were prepared from pork ileum + jejunum (TOT), heart and duodenum. TOT was fractionated by column chromatography. The insulin-releasing activities (IRA) of these materials were determined using rat islets and pieces of rat pancreas incubated with $16.6 \mathrm{mM}$ glucose. The heart and duodenum extracts were without effect on insulin release. Pancreatic glucagon and TOT significantly increased insulin release. Synthetic secretin did not increase insulin release by isolated islets. Pancreozymin had only slight effects on the insulin output by islets. Some of the fractions of TOT increased the insulin output of islets and pancreas pices. The effects of these fractions were concentration-dependent in the range 5 to $250 \mu \mathrm{g} / \mathrm{ml}$. The contents of GLI, pancreozymin and secretin in these materials are compared with their IRAs. The IRA described here is not caused by secretin, and is probably not caused by pancreozymin. There is no quantitative correlation between the GLI and the IRA of the fractions.
\end{abstract}

Les activités insulino-libératrices des extraits de l'intestin de porc

Résumé. Des extraits à l'acide éthanol ont été préparés à partir du coeur, duodénum, ileum + jejunum (TOT) du pore et TOT fractionnée sur colonne chromatographique. Avec les ilôts du rat et les morceaux de pancréas du rat, incubés dans du glucose $16.6 \mathrm{mM}$, on a déterminé pour chaque produit son activité insulinolibératrice (IRA). Les extraits de coeur et duodénum n'accrurent pas la libération d'insuline; le glucagon pancréatique et TOT l'augmentèrent significativement. La secrétine synthétique n'agit point sur la libération d'in. suline, par les ilôts isolés, mais la pancréozymine très faiblement. La production d'insuline, par les ilôts et les morceaux, fut stimulée par quelques fractions de TOT, les effets dépendant des concentrations des fractions entre 5 et $250 \mu \mathrm{g} / \mathrm{ml}$. Les contenus en GLT, pancréozymine et secrétine de ces produits furent comparés avec leurs IRAs. L'IRA, rapporté ici, n'est pas du à la secrétine, ni probablement à la pancréozymine. Il n'existe pas de relations quantitatives entre le GLI et IRA des fractions.

Extrakte aus Schweine-Eingeweiden und ihre stimulatorischen Effelte auf die Insulin-Ausschüttung

Zusammenfassung. Säureäthanolextrakte wurden aus dem Ileum + Jejunum (TOT), Herz und Duodenum des Schweins zubereitet. TOT wurde mittels Säulenchromatographie fraktioniert. Die insulinfreisetzende Aktivität (IRA) dieser Stoffe wurde an Ratteninseln und Ratten. pankreasstückchen bestimmt, die mit $16.6 \mathrm{mM}$ Glucose inkubiert worden waren. Die Herz- und Duodenumextrakte hatten keine Wirkung auf die Insulinausschüttung. Pankreasglucagon und TOT bewirkten eine signifikante Er. höhung der Insulinfreigabe. Synthetisches Sekretin bewirkte keine Erhöhung der Insulinfreisetzung aus isolierten Inseln. Pancreozymin hatte nur eine geringe Wirkung auf die Insulinproduktion der Inseln. Einige der Fraktionen von TOT erhöhten die Insulinproduktion der Inseln und der Pankreasstückchen. Im Konzentrationsbereich von $5-250 \mu \mathrm{g} / \mathrm{ml}$ waren die Wirkungen dieser Fraktionen konzentrationsabhängig. Der GLI-, Pancreozymin- und Sekretingehalt dieser Stoffe wird mit ihren. IRAs verglichen. Die hier beschriebene IRA wird nicht durch Selkretin verursacht, wahrscheinlich auch nicht durch Pancreozymin. Es besteht keine quantitative Wechselbeziehung zwischen der GLI und der IRA der Fraktionen.

Key-words: Intestine, insulin-releasing factor, GLI, islets, pancreas pieces.
Various gastro-intestinal hormones are thought to play a role in the higher insulinic response eroked by oral as distinct from intravenous administration of glucose. The present experiments demonstrate the insulinotropic effect of a gut extract on isolated rat islets and pieces of rat pancreas, and the similarity between this effect and that of pancreatic glucagon.

\section{Materials and Methods \\ Tissue Extracts}

\section{Preparation of the crude material}

$185 \mathrm{~kg}$ of pork ileum + jejunum was flushed with cold water at the earliest possible moment after slaughter. The material was then frozen on solid carbon dioxide. The frozen tissue was sliced into $75 \%$ ethanol containing $1.5 \% \mathrm{H}_{3} \mathrm{PO}_{4}$. The tissue was extracted for two hours with stirring, and the residue removed by centrifugation. The residue was extracted with $60 \%$ ethanol containing $0.5 \% \mathrm{H}_{3} \mathrm{PO}_{4}$. The combined extracts were filtered with kieselguhr, and the ethanol was evaporated in vacuo. The concentrate was filtered. Solid trichloroacetic acid (TCA) was added to the filtrate to give a final concentration of $10 \% \mathrm{w} / \mathrm{v}$. The precipitate was removed by centrifugation and extracted with $50 \%$ and then with $75 \%$ acetone, whereby the TCA precipitate was almost completely dissolved. The acetone extracts were combined, and acetone added to 
a final concentration of $97 \% .4 \mathrm{~N} \mathrm{HCl}$ was added to give a flocculent precipitate. The precipitate was isolated by centrifugation, washed twice in acetone and then dried in vacuo. This material was designated TOT, i. e., an extract of the total ileum + jejunum.

Similar preparations were made on a smaller scale from heart and duodenum, and designated heart and duodenum, respectively.

\section{Fractionation of the crude material}

a) Gel Filtration. TOT was fractionated on a $15 \times 130 \mathrm{~cm}$ column of Sephadex G-50 using $1 \mathrm{M}$ acetic acid as an eluent. The effluent contained two zones of high absorbance at $276 \mathrm{~m} \mu$ : one lying between the column void volume and 0.36 of the column volume; and the other lying between 0.55 and 0.85 of the column volume. The zones were designated I and II, respectively, and the UV-absorbing materials from the zones were isolated by freeze drying.

b) Ion Exchange Chromatography. Fraction II was dissolved in $0.01 \mathrm{M}$ tris-HCl $\mathrm{pH} 8.5$ containing $0.01 \mathrm{M}$ $\mathrm{NaCl}$. The $\mathrm{pH}$ of the solution was adjusted to 8.5 with $\mathrm{NaOH}$. A precipitate formed, which was removed by centrifugation. The supernatant was applied to a $10 \times$ $40 \mathrm{~cm}$ column of DEAE-Sephadex equilibrated with $0.01 \mathrm{M}$ tris- $\mathrm{HCl}(\mathrm{pH} 8.5)$ containing $0.01 \mathrm{M} \mathrm{NaCl}$. The sample was eluted with a gradient of $\mathrm{NaCl}(0.01 \mathrm{M}$ to $0.2 \mathrm{M}$ ) in $0.01 \mathrm{M}$ tris- $\mathrm{HCl}$ (pH 8.5). The elution was carried out at $250 \mathrm{ml} / \mathrm{h}$. The effluent was cut into fractions corresponding either to a peak in the UV absorbance or a peak in the GLI content of the fraction, Seven fractions were prepared, designated: $\alpha, \beta, \gamma, \delta$. $\varepsilon_{1}, \varepsilon_{2}$ and $\omega$. The fractions were concentrated by dialysis against dry polyethylene glycol 6000 . The dialysis residues were brought to $10 \% \mathrm{TCA}$ and the precipitates dissolved in $5 \mathrm{ml}$ of $50 \%$ acetone in water. The proteins were precipitated by the addition of $95 \mathrm{ml}$ of acetone and $4 \mathrm{~N} \mathrm{HCl}$. The acetone precipitates were centrifuged down, rinsed twice with acetone and dried in vacuo.

Fraction $\beta$ was further fractionated into $\beta_{1}$ and $\beta_{2}$ by LKB electrofocusing [2].

\section{Content of known hormones}

The glucagon-like immunoreactivites (GLI) of these fractions were determined by radioimmunoassay [3], using an anti-pork glucagon rabbit serum (K 36). GLI content is expressed in $\mathrm{ngEq} / \mathrm{mg}$ fraction, relative to standards of pork pancreatic glucagon. The pancreozymin-like immunoreactivities (PLI) of these fractions were determined by radioimmunoassay [5] using an anti-gastrin tetrapeptide rabbit serum. The PLT contents are expressed in $n g E q v / m g$ fraction relative to standards of highly purified pancreozymin ${ }^{1}$.

1 Donated by Dr. J.E. Jorpes, Karolinska Institutet, Stockholm, Sweden.
The secretin contents of the fractions were measured by a cat-bioassay [6], using Boots' Secretin as a standard.

\section{Insulin-releasing activities}

The insulin-releasing activities of the fractions were determined by incubating them with isolated rat islets and with pieces of rat pancreas. The effects of pork pancreatic glucagon (NOVO, containing less than $0.01 \%$ of insulin), synthetic secretin (Squibb, batch SQ 18, 773-ES-XXIX-109, approximate specific activity 4000 C.U./mg) and highly purified pancreozymin $^{1}$ on the release of insulin by islets were also studied.

\section{Incubation of isolated islets}

A bicarbonate-buffered medium equilibrated with 95\% $\mathrm{O}_{2}: 5 \% \mathrm{CO}_{2}$ and containing human serum albu$\min (1 \% \mathrm{w} / \mathrm{v}), 5 \mathrm{mM}$ sodium fumarate, glutamate and pyruvate [7] (fortifier) was used in the majority of the islet experiments. The medium contained 250 K.I.U. of kallikrein inhibitor/ml (Trasylol, Bayer). This drug protects polypeptides from lytic factors present in acinar tissue [9], and in blood [1], but does not modify the rate of insulin secretion induced by glucose [9].

Islets of Langerhans were isolated from the pancreases of fed, 200 or $400 \mathrm{~g}$ male Wistar rats by collagenase digestion [8]. The islets from two or three rats were pooled for each experiment. The pooled islets were preincubated for one hour at $37^{\circ} \mathrm{C}$ in medium containing $8.3 \mathrm{mM}$ glucose. The islets were then transferred to icecold medium and distributed among the incubation flasks. Six to eight islets were added to each flask. Each flask contained $2 \mathrm{ml}$ of bicarbonate medium with a glucose concentration of 8.3 or $16.6 \mathrm{mM}$. Equal numbers of flasks were prepared with glucose alone and with glucose plus the fraction to be tested. The flasks were gassed with $95 \% \mathrm{O}_{2}: 5 \% \mathrm{CO}_{2}$ and incubated for $90 \mathrm{~min}$ at $37^{\circ} \mathrm{C}$.

After the incubation, aliquots of the media were diluted for the assay of their insulin contents. The insulin in the media was determined in duplicate by radioimmunoassay [4]. Rat insulin (NOVO, lot $R 464$, potency $20 \mathrm{U} / \mathrm{mg}$ ) was used as a standard.

The insulin contents of the materials tested were determined in the same system. All the values presented are corrected for the insulin added to the media with the test substances.

The results are expressed as the mean difference in insulin release ( $\mu \mathrm{U} /$ islet. $90 \mathrm{~min}$ incubation) between the flasks containing glucose alone, and the flasks containing glucose plus the fraction to be tested. The significance of the difference was determined by Student's " $t$ " test (d,f. $=2 n-2)$.

\section{Incubation of pancreatic tissue}

Small pieces of rat pancreatic tissue were incubated in a bicarbonate-buffered medium equilibrated with 
$95 \% \mathrm{O}_{2}: 5 \% \mathrm{CO}_{2}$ and containing bovine serum albumin $(0.5 \% \mathrm{w} / \mathrm{v})$. The medium contained 625 K.I.U. of kallikrein inhibitor/ml (Trasylol, Bayer). Anti-insulin guinea-pig serum (prepared and kindly donated by Dr. P.H. Wright, Indiana University, Indianapolis) was added to the medium as required.

The rate of insulin secretion was calculated from the partial neutralization of the antibodies, and is expressed as microunits of insulin secreted per $\mathrm{mg}$ tissue during 60 minutes incubation at $37^{\circ} \mathrm{C}$. Full details for the method of incubation and assay of the antibodies are given elsewhere $[10,15]$. In one or more experiments, insulin secretion was measured in an equal number of flasks $(n)$ containing a substrate alone (glucose or leucine), and the same substrate with the added extract. Mean differences (d.f. $=2 n-2$ ) in secretion rates found under these conditions are quoted, together with the mean absolute rates of secretion obtained in all experiments where only the substrate was present in the medium. Theophylline $(1.4 \mathrm{mM})$ and mannoheptulose $(2.5 \mathrm{mM})$ were added to the medium as indicated in the results section. Isoosmolarity was maintained in all cases by reducing the concentration of sodium chloride.

The extracts used were a pork gut extract (TOT), a duodenum extract, a heart extract, and fractions of TOT comparatively rich in GLI (fractions $\beta_{1}$ and $\varepsilon_{1}$ ). Preliminary results obtained with high concentrations $(1.0 \mathrm{mg} / \mathrm{ml})$ of the gut extract [11] might correspond to a substrate effect and are, therefore, not included in the present account.

\section{Results}

The hormonal contents of the fractions tested are shown in Table 1.

Table 1. Secretin, GLI and PLI in gut extracts and in fractions of TOT

\begin{tabular}{lccc}
\hline Fraction & $\begin{array}{l}\text { Secretin } \\
\text { C.U./mg }\end{array}$ & $\begin{array}{l}\text { GLI } \\
\text { ngEqv/mg }\end{array}$ & $\begin{array}{l}\text { PLI } \\
\text { ngEqv/mg }\end{array}$ \\
\hline Duodenum & $\sim 0.02$ & 0 & - \\
TOT & $0.2-0.04$ & 280 & 17 \\
I & 0 & 0 & - \\
II & - & 600 & - \\
$\alpha$ & 0.2 & 150 & 11 \\
$\beta$ & $1-2$ & 1000 & 160 \\
$\beta_{1}$ & - & 490 & - \\
$\gamma$ & $\sim 0$ & 116 & 28 \\
$\delta$ & $\sim 0$ & 216 & 21 \\
$\varepsilon_{1}$ & $\sim 0$ & 3500 & 54 \\
$\varepsilon_{2}$ & $\sim 0$ & 1500 & 32 \\
$\omega$ & $\sim 0$ & 300 & 8 \\
\hline
\end{tabular}

TOT contains some secretin and some GLI. Fraction II contains all the GLI present in TOT, but only about one-half of the protein. Secretin is restricted to fractions $\alpha$ and $\beta$ of TOT. GLI is found in all the fractions derived from fraction II of TOT, with high concentrations located in $\beta, \beta_{1}, \varepsilon_{1}$ and $\varepsilon_{2}$. TOT contains $17 \mathrm{ngEqv}$ of PLI/mg. Fraction $\beta$ contains $160 \mathrm{ngEqv} /$ $\mathrm{mg}$. The other fractions derived from TOT contain between 8 and $54 \mathrm{ngEqv}$ of PLI/mg.

The effects of these fractions on the release of insulin by isolated rat islets are summarized in Tables 2, 3 and 4.

At $50 \mu \mathrm{g} / \mathrm{ml}$, TOT did not stimulate insulin release in the presence of $8.3 \mathrm{mM}$ glucose, but did so at 5 and $50 \mu \mathrm{g} / \mathrm{ml}$ in the presence of $16.6 \mathrm{mM}$ glucose (Table 2). All other incubations were carried out with $16.6 \mathrm{mM}$ glucose. Unless otherwise stated, $50 \mu \mathrm{g} / \mathrm{ml}$ of the substances to be tested were added to the media. The heart and duodenum extracts were without effect. Secretin was without effect at a concentration $(10 \mathrm{ng} / \mathrm{ml})$ equivalent to that added with $50 \mu \mathrm{g} / \mathrm{ml}$ of fraction $\beta$. Glucagon significantly stimulated insulin release. Fraction I was inert whereas Fraction II significantly increased insulin release. Fraction $\alpha$ was without effect. Beta slightly increased insulin release. Gamma, $\delta, \varepsilon_{1}$ and $\varepsilon_{2}$ significantly increased insulin release by about $40-70 \%$ of the release observed with glucose alone. Omega contained $220 \mu \mathrm{U}$ of insulin/50 $\mu \mathrm{g}$. The effect of this fraction on the insulin output of islets was equal to that which would be expected from its content of insulin.

Pancreozymin was examined in a separate series of experiments in which its effects were compared with those of $\beta, \beta_{1}$ and $\gamma$.

Table $3(A$ and $B$ ) shows that pancreozymin at 1.5 and $10 \mathrm{ng} / \mathrm{ml}$ was without statistically significant effect on the insulin output of islets incubated in the presence of $16.6 \mathrm{mM}$ glucose. In the same experiments $\gamma$ at $50 \mu \mathrm{g} / \mathrm{ml}$ (equal to about $1.5 \mathrm{ngEqv}$ of $\mathrm{PLI} / \mathrm{ml}$ ) significantly stimulated insulin release.

Removal of the fortifier from the incubation medium reduced the insulin released in the presence of glucose alone (compare lines 1 and 5 in Table 3) without markedly decreasing the effect of added fractions. Pancreozymin was therefore compared with $\beta$ and $\beta_{1}$ in buffer without added fortifier so that minor effects of these materials could be exposed.

Beta and $\beta_{1}$ weakly stimulated insulin release (Table 3, D). Pancreozymin at $5 \mathrm{ng} / \mathrm{ml}$, which was approximately equal to the amount of PLI added with $50 \mu \mathrm{g}$ of $\beta / \mathrm{ml}$, slightly increased insulin release $(0.025$ $<P<0.05$ ). At $250 \mathrm{ng} / \mathrm{ml}$ pancreozymin weakly inhibited insulin release $(P=0.001)$.

Fractions $\gamma, \delta$ and $\varepsilon_{1}$ were added to islets at concentrations ranging between 5.0 and $250 \mu \mathrm{g} / \mathrm{ml}$ (Table 4). Between 5.0 and $50.0 \mu \mathrm{g} / \mathrm{ml}$, the effects of all the fractions increased. There was no significant difference between the effects of the fractions in this concentration range. Between 50 and $250 \mu \mathrm{g} / \mathrm{ml}$, the 
effect of $\gamma$ and $\varepsilon_{1}$ increased, whereas the effect of $\delta$ decreased.

The results obtained by incubation of rat pancreatic tissue are summarized in Table $\mathbf{5}$.
TOT had no effect in the absence of glucose, but it significantly increased the rate of insulin secretion induced by glucose $(16.6 \mathrm{mM})$. This potentiating effect progressively faded out as the concentration of the

Table 2. The effects of extracts and fractions on the insulin output of isolated islets

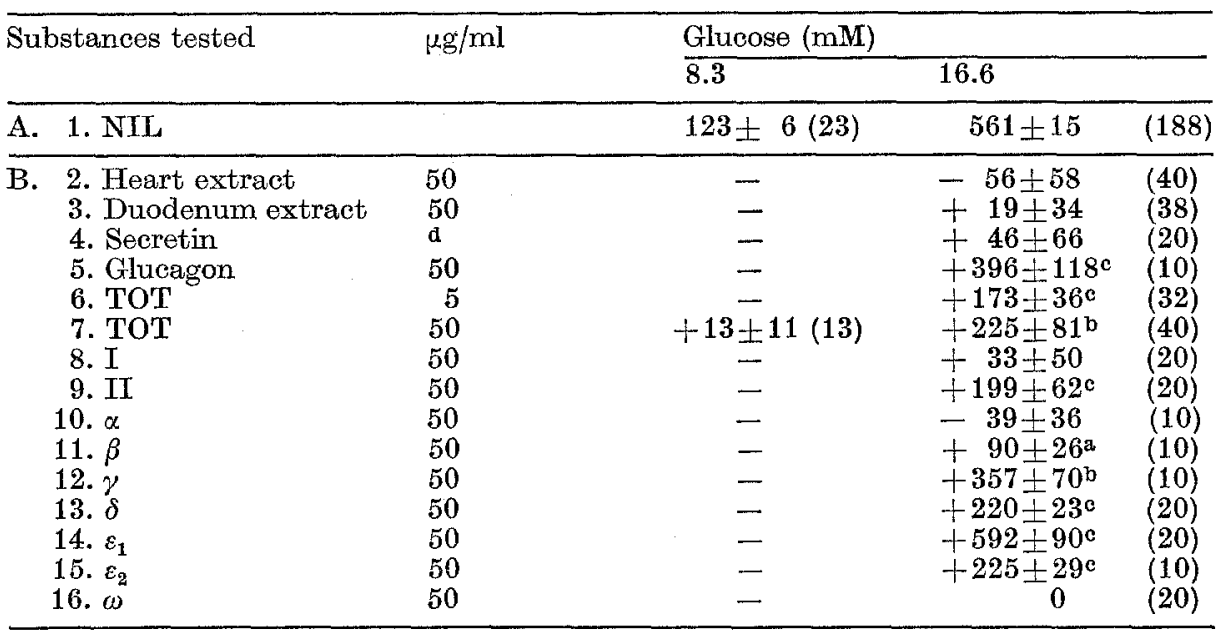

The islets were obtained from $400 \mathrm{~g}$ rats.

A. Mean insulin output ( $\mu$ U/islet. $90 \mathrm{~min} \pm \mathrm{S} . \mathrm{E} . \mathrm{M}$.) of islets incubated with glu. cose alone.

B. Effects of added materials as mean changes $(+$ or -$)$ in insulin output $(\mu \mathrm{U} /$ islet.90 min \pm S.E.M.) with their statistical significances.

a $P<0.05$.

b $P<0.02$.

c $P<0.005$.

The number of observations is in brackets.

d Secretin at $10 \mathrm{ng} / \mathrm{ml}$.

Table 3. The effect of $\beta, \beta_{1}, \gamma$ and pancreozymin on the insulin output of isolated islets

\begin{tabular}{|c|c|c|}
\hline Substances tested & Glucose (16.6 & $\mathrm{mM}$ ) \\
\hline A $1 . \mathrm{NH}$ & $387 \pm 16$ & (19) \\
\hline $\begin{array}{l}\text { B 2. } \gamma(50 \mu \mathrm{g} / \mathrm{ml}) \\
\text { 3. Pancreozymin }(1.5 \mathrm{ng} / \mathrm{ml}) \\
\text { 4. Pancreozymin }(10 \mathrm{ng} / \mathrm{ml})\end{array}$ & $\begin{array}{l}+\quad 163 \pm 37 \mathrm{c} \\
+\quad 37 \pm 20 \\
+\quad 44 \pm 26\end{array}$ & $\begin{array}{l}(20) \\
(20) \\
(20)\end{array}$ \\
\hline C 5. NIL & $282 \pm 18$ & (36) \\
\hline $\begin{array}{l}\text { D } 6 . \beta(50 \mu \mathrm{g} / \mathrm{ml}) \\
\text { 7. } \beta_{1}(50 \mu \mathrm{g} / \mathrm{ml}) \\
\text { 8. Pancreozymin }(5 \mathrm{ng} / \mathrm{ml}) \\
\text { 9. Pancreozymin }(250 \mathrm{ng} / \mathrm{ml})\end{array}$ & $\begin{array}{l}+\quad 38 \pm 18^{\mathrm{a}} \\
+\quad 64 \pm 14^{\mathrm{c}} \\
+\quad 30 \pm 12^{\mathrm{b}} \\
+\quad 30 \pm 11^{\mathrm{b}}\end{array}$ & $\begin{array}{l}(15) \\
(15) \\
(19) \\
(19)\end{array}$ \\
\hline
\end{tabular}

The islets were obtained from $200 \mathrm{~g}$ rats and incubated in a bicarbonate-buffered medium with $(A, B)$ or without $(\mathrm{C}, \mathrm{D})$ added fortifier.

$A$ and $C$ : Mean insulin output ( $\mu$ U/islet. 90 min. \pm S.E.M.) of islets incubated with glucose alone.

$B$ and D: Effects of added substances as mean changes $(+$ or -$)$ in insulin output ( $\mu$ U/islet. $90 \mathrm{~min} . \pm$ S.E.M.) with their statistical significances.

a $P<0.05$.

b $P<0.02$.

c $P<0.005$.

The number of observations is in brackets. extract in the incubation medium was decreased from 125 to $16 \mu \mathrm{g} / \mathrm{ml}$. Mannoheptulose inhibited both the stimulant action of glucose and the enhancing effect of TOT.

Over a wide range of concentrations ( 5 to $64 \mu \mathrm{g} / \mathrm{ml}$ ), and at 2 glucose levels $(8.3 \mathrm{mM}$ and $16.6 \mathrm{mM})$, the duodenum extract exerted only minor effects, a barely significant $(0.05<P<0.03)$ stimulant effect being observed under only one experimental condition. The heart extract did not demonstrate any stimulant effect.

The fractions rich in GLI $\left(\beta_{1}\right.$ and $\left.\varepsilon_{1}\right)$ influenced insulin secretion in the same manner as TOT. They had little if any effect in the absence of glucose, but markedly enhanced the rate of secretion induced by glucose $(16.6 \mathrm{mM})$. This potentiating action disappeared as the concentration of these fractions in the incubation medium was decreased from 10 to $2 \mu \mathrm{g} / \mathrm{ml}$.

Since leucine- and glucose-induced secretion are similar in that they are both potentiated by theophylline [12], the effects of the intestinal extracts were also investigated in the presence of leucine. This amino acid was used in a high concentration $(25.0 \mathrm{mM})$ previously shown to significantly increase the basal rate of insulin secretion in the present system [12]. The gut extract significantly enhanced the stimulant effect of leucine 
whereas, at the same concentration $(50 \mu \mathrm{g} / \mathrm{ml})$, the duodenum and heart extracts were ineffective.

As shown in Table 5, the results obtained with TOT and the fractions $\beta_{1}$ and $\varepsilon_{1}$ are comparable with those obtained in previous experiments with pancreatic glucagon or theophylline. which stimulates insulin secretion in vitro [12]. Duodenum and heart extracts apparently do not contain such a factor.

The patterns of insulin-releasing activities detected by isolated islets and by pieces of pancreas are remarkably similar. Both methods detected insulin-

Table 4. The effects of different concentrations of gut fractions on the insulin output of isolated islets

\begin{tabular}{|c|c|c|c|c|}
\hline A. & & B. & & \\
\hline Glucose & $\mu \mathrm{g} / \mathrm{ml}$ & Fractions Tested & & \\
\hline $16.6 \mathrm{mM}$ & & $\gamma$ & $\delta$ & $\varepsilon_{1}$ \\
\hline $\begin{array}{l}\text { 1. } \\
\text { 2. } \quad 339 \pm 13(18) \\
\text { 3. }\end{array}$ & $\begin{array}{r}5 \\
50 \\
250\end{array}$ & $\begin{array}{r}+97 \pm 26^{\mathrm{b}}(6) \\
+135 \pm 28^{\mathrm{c}}(6) \\
+163 \pm 38^{\mathrm{c}}(6)\end{array}$ & $\begin{array}{l}+50 \pm 26^{\mathrm{b}}(6) \\
+123 \pm 25^{\mathrm{c}}(6) \\
+\quad 62 \pm 27^{\mathrm{b}}(6)\end{array}$ & $\begin{array}{l}+78 \pm 32^{\mathrm{b}}(6) \\
+123 \pm 38^{\mathrm{b}}(6) \\
+163 \pm 44^{\mathrm{c}}(6)\end{array}$ \\
\hline
\end{tabular}

A. Mean insulin output ( $\mu \mathrm{U} /$ islet.90 min \pm S.E.M.) of islets incubated with glucose alone. The islets were obtained from $200 \mathrm{~g}$ rats.

B. Effect of fractions as mean increases in insulin output ( $\mu$ U/islet $\cdot 90$ min \pm S.E.M.) with their statistical significances.

b $P<0.02$.

c $P<0.005$

The number of observations is in brackets.

Table 5. The effects of gut extracts, glucagon and theophylline on the insulin output of pancreas pieces

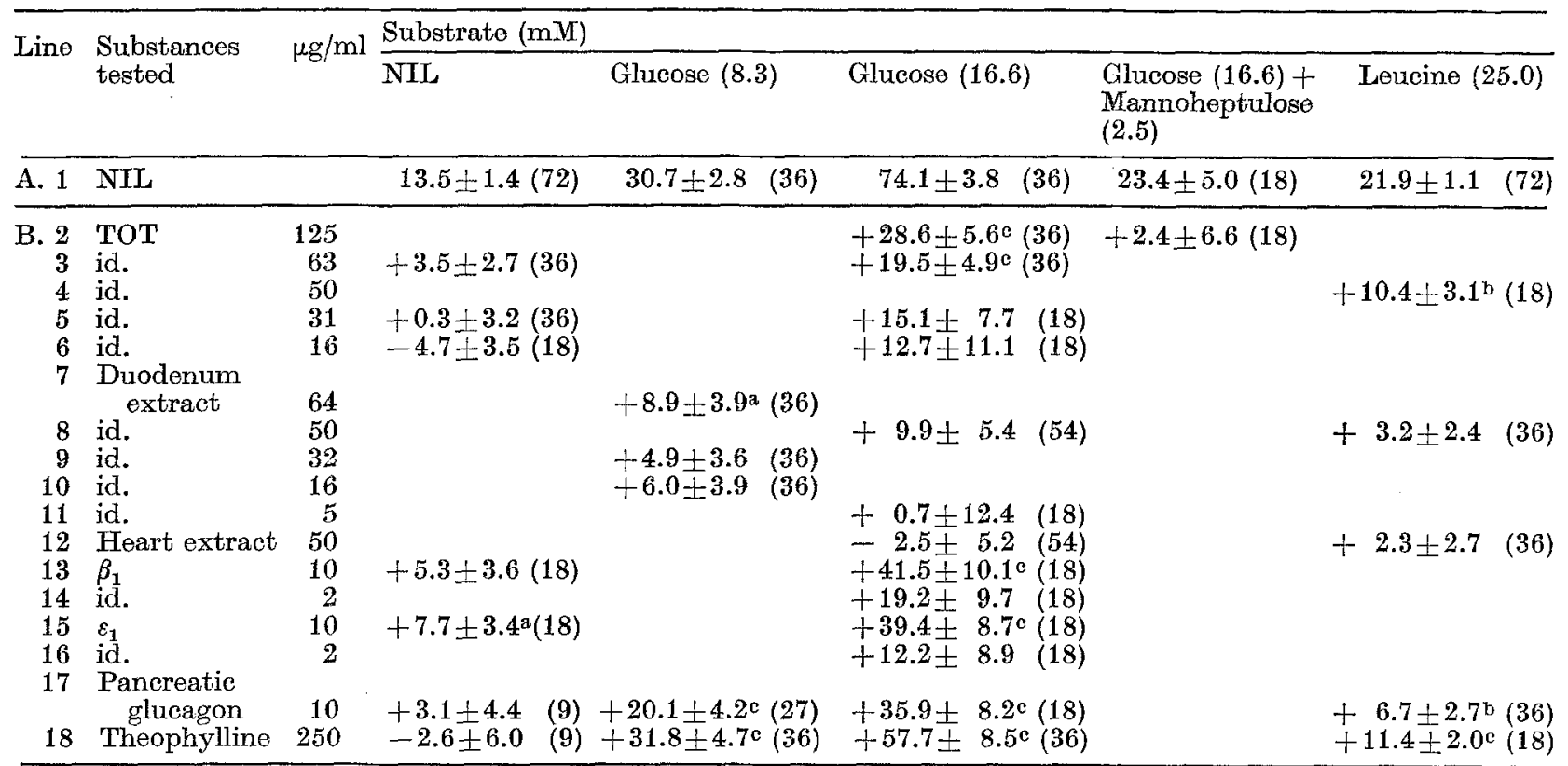

A. Mean insulin output ( $\mu \mathrm{U} / \mathrm{mg} \cdot 60 \mathrm{~min} \pm$ S.E.M.) by tissue incubated in media containing only substrates.

B. Effects of added materials are quoted as mean changes $(+$ or -$)$ in insulin output $(\mu \mathrm{U} / \mathrm{mg} \cdot 60 \mathrm{~min} \pm \mathrm{S} . \mathrm{E} . \mathrm{M}$. with their statistical significances.

a $P<0.05$.

b $P<0.02$.

c $P<0.001$.

The number of observations is in brackets.

\section{Discussion and Conclusions}

The present results confirm previous reports suggesting that the pork ileum + jejunum contain a factor releasing activity in the extract of jejunum + ileum (TOT), and did not detect insulin-releasing activity in the extracts of heart and duodenum. The methods differ in that the insulin release from pancreas pieces was 
strongly stimulated by $\beta_{1}$, whereas the insulin release from islets was weakly increased by $\beta_{1}$. This difference may be due to the two tissues having different sensitivities to the constituents of $\beta_{1}$.

The material responsible for the enhancement of glucose-mediated insulin release by islets is not secretin, for the most active fractions were devoid of secretin, and secretin itself did not increase insulin release.

The fractions which contain the most insulin-releasing activity contained very little PLI. Furthermore, the fraction containing the most PLI was a weak stimulator of the release of insulin by islets, and pancreozymin itself was either a weak stimulator or a weak inhibitor of insulin release. It is concluded that pancreozymin is probably not the cause of the insulin releasing activities detected by the use of isolated islets. The small amounts of PLI present may have modified the insulin-releasing activities of other com. ponents of the fractions.

Our data do not permit us to decide whether the material possessing GLI is associated with, or is the causative agent of insulin-releasing activity. Insulinreleasing activity follows GLI through the purification steps, but some active fractions ( $\gamma$ and $\delta$ ) contain little GLI whereas $\beta$, which is rich in GLI, has but little insulin releasing activity on islets. Beta $a_{1}$, a GLIcontaining subfraction of $\beta$, contained significant amounts of insulin-releasing activity on both islets and pancreas pieces.

The modes of action of TOT and the fractions derived from it on pancreas pieces are comparable with those previously observed with pancreatic glucagon [13]. In both cases the stimulant action was dependent upon the presence of a substrate, either glucose or leucine, in the incubation medium. It is therefore possible that the gut factor, whatever its nature (gut GLI, incretin), activates the $\beta$-cell's adenylcyclase as does pancreatic glucagon. The inhibition by mannoheptulose of the stimulant action of glucose and the potentiating effect of the gut factor is another argument in favour of such a hypothesis. Indeed, this pattern is only observed with drugs acting through the $\beta$-cell's adenylcyclase $/ 3^{\prime}, 5^{\prime}$ cyclic AMP/phosphodiesterase system [13], and is different from that found with other insulinotropic agents, such as the non-carbohydrate metabolites [12] or the sulphonylureas [14].

It is concluded that an extract of pork ileum + jejunum contains a factor, or factors, which enhance glucose-induced insulin release by rat islets and pieces of rat pancreas in vitro. This activity is not caused by secretin and is probably not caused by pancreozymin. The insulin-releasing activity of fractions of the gut extract is associated with the presence of GLI. The mode of action of the extract shows similarities to that of pancreatic glucagon.

Acknowledgements. The authors acknowledge the technical assistance of Mrs. L. Drube, Miss E. Jensen, Mrs. E. Gammelgaard and Mrs. C. Meding.

\section{References}

1. Eisentraut, A.M., Whissen, N., Unger, R.H.: Incubation damage in the radioimmunoassay for human glucagon and its prevention with Trasylol. Amer. J. med. Sci. 255, 137-142 (1968).

2. Haglund, H.: Isoelectric focusing in natural $\mathrm{pH}$ gradients - a technique of growing importance for fractionation and characterisation of proteins. Science Tools 14, 17-23 (1967).

3. Heding, L.G.: Glucagon antibodies for the radioimmunoassay of pancreatic and gut glucagon. Abstracts, European Association for the Study of Diabetes, 4 th annual meeting. Diabetologia 4, 392-393 (1968).

4. - A simplified insulin radioimmunoassay method in "Labelled Proteins in Tracer Studies", Ed. L. Donato et al., pp. 345-351. Brussels: Euratom 1966.

5. Jeffcoate, S.L.: Radioimmunoassay of gastrin: specificity of gastrin antisera. Scand. J. Gastroenterology, $4,457-461(1969)$.

6. Jorpes, J.E., Mutt, V.: On the biological assay of secretin. The reference standard. Acta physiol. scand. 66, 316-325 (1966).

7. Krebs, H.A.: Body size and tissue respiration. Biochim. biophys. Acta 4, 249-269 (1950).

8. Lacy, P.E., Kostianovsky, M.: Method for the isolation of intact islets of Langerhans from the rat pancreas. Diabetes 16, $35-39$ (1967).

9. Malaisse, W., Malaisse-Lagae, F., King, S.: Quantitative and qualitative aspects of islet function in the rat. J. Lab. clin. Med. 71, 56-64. (1968).

10. - - Wright, P.H.: A new method for the measurement of in vitro pancreatic insulin secretion. Endocrinology 80, $99-108$ (1967).

11. - - Insulin secretion by isolated islets of Langerhans. Effects of pancreatic and intestinal hormones. Acta diabetologica latina 5, 64-76 (1968).

12. - - Stimulation of insulin secretion by non-carbohydrate metabolites. J. Lab. clin. Med. 72, 438-448 (1968).

13. - - Mayhew, D.A.: A possible role of the adenylcyclase system in insulin secretion. J. clin. Invest. 46, $1724-1734$ (1967).

14. - - - Wright, P.H.: in "Tolbutamide ... after ten yoars". Butterfield, W.J.H., van Westering, W., ed. Excerpta Medica Foundation, International Congress Series 149, 49 (1967).

15. Wright, P.H., Malaisse, W.: A simple method for the assay of guinea-pig anti-insulin serum. Diabetologia $2,178-188(1966)$.

Dr. A.J. Moody

Novo Research Institute

Fuglebakkevej 115

Copenhagen/Denmark 